Article

\title{
Feminism as Power and Resistance: An Inquiry into Different Forms of Swedish Feminist Resistance and Anti-Genderist Reactions
}

\author{
Mona Lilja ${ }^{1, *}$ and Evelina Johansson ${ }^{2}$ \\ ${ }^{1}$ School of Global Studies, University of Gothenburg, 41314 Gothenburg, Sweden; E-Mail: mona.lilja@gu.se \\ ${ }^{2}$ Department of Cultural Studies, University of Gothenburg, 41314 Gothenburg, Sweden; E-Mail: evelina.johansson@gu.se \\ * Corresponding author
}

Submitted: 11 April 2018 | Accepted: 13 August 2018 | Published: 22 November 2018

\begin{abstract}
This article explores how resistance and power are intertwined within the field of mainstream Swedish feminism, by analyzing some of its more visible expressions and strategies. These feminist resistance strategies could be described as circulating resistance (e.g., the \#metoo campaign), public assemblies, the more subtle "disciplinary resistance", and state feminism. The article illustrates how these different forms of resistance fuel different reactions from movements that reiterate different discourses of "anti-genderism". In addition, some forms of feminism (state feminism and feminist disciplinary resistance) sometimes develop into, or overlap with, different technologies of power.
\end{abstract}

\section{Keywords}

anti-genderism; feminism; gender; popular assemblies; power; resistance; Sweden; state feminism

\section{Issue}

This article is part of the issue "Gender Equality and Beyond: At the Crossroads of Neoliberalism, Anti-Gender Movements, 'European' Values, and Normative Reiterations in the Nordic Model”, edited by Lena Martinsson (University of Gothenburg, Sweden), Diana Mulinari (Lund University, Sweden) and Katarina Giritli Nygren (Mid Sweden University, Sweden).

(C) 2018 by the authors; licensee Cogitatio (Lisbon, Portugal). This article is licensed under a Creative Commons Attribution 4.0 International License (CC BY).

\section{Introduction}

This article explores how resistance and power are intertwined within the field of mainstream Swedish feminism by analyzing some of its more visible expressions and strategies. These feminist resistance strategies could be described as circulating resistance (e.g., the \#metoo campaign), public assemblies, the more subtle "disciplinary resistance", and state feminism. The article demonstrates, among other things, how these different forms of resistance fuel different reactions from movements that reiterate different discourses of "anti-genderism". In addition, some forms of feminism (state feminism and feminist disciplinary resistance) sometimes develop into, or overlap with, different technologies of power.

Research on resistance often addresses more organized forms of resistance/social movements or demonstrates more individual or everyday resistance practices.
In the latter case, the concept of everyday resistance is often suggested as a concept that differs from or complements research on organized resistance (Lilja \& Vinthagen, 2018; Scott, 1990, p. 198). However, when looking at feminist resistance, the resistance takes different expressions that indicate an assemblage of resistance practices that interact with each other. Overall, this resistance is performed by different subjects in different contexts through large organized groups as well as by individuals. Feminist resistance manifests itself through public assemblies, circulating discourses, by state feminism, or in a more disciplinary manner. Different practices of feminist resistance are related to other practices of resistance and the discourses of feminism. These discourses of feminism are not homogeneous, but often conflicting. Furthermore, feminist resistance sometimes transcends into more dominant forms of knowledge-such as in the case of state feminism. The Nordic model of state fem- 
inism has, as we will demonstrate in the next coming sections, both contributed to some important feminist achievements but also fallen short at certain times.

Moreover, feminist resistance itself not only profits on, or challenges, but also generates different power relations. Today different forms of feminism interact with various xenophobic, often right-wing, political movements. Roman Kuhar and David Paternotte (2017) suggest the notion of the "anti-gender" movement to describe mobilizations and campaigns that target gender and sexual equality (Kuhar \& Paternotte, 2017, p. 253). These movements reiterate and build upon binary notions of different social categories and their struggles are against reproductive technologies, anti-discrimination policies, gender mainstreaming, sex education, transgender rights, and so on (Kuhar \& Paternotte, 2017, pp. 258-259).

This article studies feminism as resistance to and exercise of power through an analysis of different forms of feminism and anti-genderism. As indicated above, different forms of feminist-inspired resistance exist simultaneously and are performative of and intertwined in other forms of feminist resistance. It is noteworthy that so far relatively few scholars have elaborated on the multitude of resistance and the inter-linkage of shifting forms of resistance in general, as well as how acts of individual, everyday, or discursive resistance entangle with more organized and sometimes mass-resistance activities. This article seeks to respond to this challenge by exploring how the multitude of and relationships between different forms of resistance are intertwined in power.

\section{Some Notes on Methodology, Methods, and Material}

Methodologically, this article draws upon discourse analysis as a way of unpacking the taken-for-granted and demonstrates the different discursive struggles, the multitude of forms of resistance, and the discourses that underlie, motivate, and oppose feminist struggles. Discourses, which are constructed through language, produce social life and inform who we are, how we should act, they define our place of existence and are essential for understanding resistance. (Gee \& Handford, 2012, p. 1; Peeples, 2015). Language here is embraced in a broad sense including both the linguistic as well as the extra-linguistic, and hence practices, images, sounds, words, sentences, and writings are all seen as representations of different discourses.

In social science, resistance has been embraced in its complexity. We have reviewed and synthesized some of the diverse uses of the term resistance with the aim of identifying some of the important themes or resistance practices that can be observed in the literature. These themes or resistance practices have served as a point of departure for coding our data. Inspired by Butler's (2015) notion of public assemblies, Halley, Kotiswaran, Rebouché and Shamir's (2018) notion of governance feminism and Foucault's $(1981,1991)$ notions of disciplinary power as well as resistance as repetitions, which undermine the force of normalization, we have analyzed the feminist discourses and practices in today's Sweden and outlined four different feminist strategies: circulating resistance (e.g., the \#metoo campaign), public assemblies, the more subtle "disciplinary resistance", and state feminism. We are aware, by following the works of James Scott (1990), that there is probably also feminist resistance, which is more hidden than the themes elaborated above. However, this resistance is not covered in this article as we have not collected data that demonstrate these more hidden strategies of resistance.

Inspired by the previously-mentioned elaborations of political struggles, this article analyzes the discourses that revolve around gender and feminist-inspired resistance and power. We have drawn on secondary material in the form of books and articles that have been both inspirational and informative in helping us to identify feminist political actions; these include different scholarly documents and media texts, such as debate articles. Together with different Facebook pages and/or Facebook notifications, these have provided us with rich and differentiated material with competing and contradictory stories, from which we have identified/constructed the four feminist resistance strategies addressed in this article. In particular, we searched for and analyzed debate articles (from the last two years) that revolve around different gender issues that were written for the Swedish newspaper Svenska Dagbladet (SvD). Lately, this newspaper has given space for different opinions (for example, Yvonne Hirdman and Ivan Arpi) in regard to gender equality issues.

\section{Feminism and Anti-Genderism on the Rise}

Today, white and non-white cis women, trans-women, bisexuals, and homosexuals are experiencing numerous, often intersecting, forms of oppression involving, for instance, low-status, reductive images, narrow images of identity, lower salaries, sexual abuse, and violence. These material and visible expressions of power are grounded in different discourses that essentialize, grade, naturalize, and marginalize these groups in different ways and to different degrees. Thus, the power relations that are opposed by feminist forms of resistance are both discursive and material in their character. At the same time, the neoliberal destabilization of certain status orders has offered a transgressive framework for the emancipation of certain segments of these groups (Fraser \& Jaeggi, 2018, p. 200). While economic inequalities are steadily worsening, some researchers claim that cultural oppression-which has direct material effectsis actually decreasing (Nilsson \& Nyström, 2018). Hence, neoliberalism makes some struggles for equality easier, while others appear to be more distinctly in conflict with the economic order.

While different forms of feminism, in general, refer to the belief that humans, no matter what their gen- 
der is, deserve equality of opportunity, treatment, respect, and social rights, this belief is formulated, promoted, and understood in various ways. Some stress the intersectional character of all forms of oppression and argue that "women" should be embraced in the crossroads between different forms of categorization or discrimination. Others emphasize the rights of those who perform identity positions that are related to LGBT (lesbian, gay, bisexual, and transgender) issues or embrace class differences, or promote a more liberal form of feminism. Different approaches to matter also distinguish and separate different feminist strands. Feminist resistance is thereby often formulated from specific comprehensions of, for example, identity, power, and matter. In line with this, feminist resistance is diverse, conflicting, interlinked and takes different expressions due to its relations with other forms of feminism.

Moreover, feminist-inspired concerns about equality and the practices carried out to reach such equality, give rise to-especially when successful-various backlashes (Faludi, 1991; Fraser \& Jaeggi, 2018) and not only challenge power relations, but also provoke them. Kuhar and Paternotte, for example, conclude that anti-gender movements often present themselves "in opposition to clearly identified actors such as feminists, LGBT activists, specific elites and others" (Kuhar \& Paternotte, 2017, p. 256). This, as we will see in the below analysis, is the case in Sweden, where different feminist-inspired movements and practices seem to fuel different reactions in terms of anti-genderism. This makes it reasonable to conclude that the discourses and practices of anti-genderism should, among other things, be analyzed in relation toand partly as a reaction to and interlinking with-the manifold and messy forms of feminism.

Kuhar and Paternotte argue that despite national specificities there are many similarities in the rhetoric of anti-gender activists across Europe. Common patterns in the mobilizations can be identified across borders (Kuhar \& Paternotte, 2017, p. 256). This includes shared discourses and a similar repertoire of actions and strategies. It is these new forms of activism that are against, among other things, "gender ideology", gender mainstreaming, and gender studies (Kuhar \& Paternotte, 2017, pp. 258-259). Overall, the movements' target issues are related to the control over one's physical body. They also question the potential for self-realization through one's identity and (non-heteronormative) partnerships (Kuhar \& Paternotte, 2017, p. 256). More specifically, rights and issues that are under attack from these movements include: reproductive rights, LGBT rights, gender studies, sex and gender education, and democracy issues related to these (Kuhar \& Paternotte, 2017, p. 256; Peto, 2016).

Different reactions to feminist resistance should be contextualized in order to understand why feminism sometimes fuels anti-genderism. Nancy Fraser has-in an argument that fits well with the research of Nilsson and Nyström (2018)-convincingly argued that main- stream feminism has been able to use the neoliberal destabilization of the social order (with its paternalistic and protective traits) in order to liberate certain groups of women, while other groups (particularly white working class men) have lost some of their privileges due to this destabilization of the existing order. The hatred towards women, LGBT people, and others-whose subordination is partly, but not only, connected to status - could, therefore, be understood as a reaction to this partial loss of power and status (Fraser \& Jaeggi, 2018, p. 200ff.). From the perspective of having lost previous privileges, feminists are understood as the ones being in power and therefore severely threatening male supremacy.

By following the works of Kuhar and Paternotte, anti-genderism in Europe not only includes angry white men, but also complex networks of different actors, antiabortion groups, religious groups, family associations, nationalists and populists, far-right groups, and others (Kuhar, 2015; Kuhar \& Paternotte, 2017, p. 259; Peto, 2016). In addition, and most importantly, the discourses of gender and sexual equality seem to mobilize people who, in their everyday lives, are active on internet forums, in Facebook groups, and on the editorial pages of newspapers, thus spreading the messages of the antigender movement. Together, not only the movements themselves but also the individual followers make the anti-gender discourse grow.

In Sweden, the anti-genderism and the emotional regime of hate towards feminism, as well as towards females embodying feminist agendas, is increasingly connected to anti-immigration sentiments. At the same time, racist and anti-immigration arguments often emphasize and make use of gender equality norms. As Diana Mulinari points out in her research on women voting for the nationalist party the Sweden Democrats, the party-though in a paradoxical manner-actually argues for the formal equality of men and women (Mulinari, 2016, p. 147). Moreover, Mulinari identifies similarities between the rhetoric of the Sweden Democrats and hegemonic Swedish feminism (Mulinari, 2016, p. 157).

However, the "progressive" feminist discourse of antiimmigration movements in Sweden can be understood to be on the decline. One example would be that the Sweden Democrats, who in their political campaign prior to the 2010 election put forward various "pro-feminist" arguments, yet their campaign before the 2018 elections voiced that sentiment to a much lesser degree-it contained proposals of a more restrictive abortion policy and less gender pedagogy within the Swedish education system (Sverigedemokraterna, 2017). One way of understanding this change would be that the Sweden Democrats, due to the increasing support they enjoy, do not need to use hegemonic arguments (such as female emancipation) to legitimize their politics. Overall, the connections between various feminist struggles and anti-feminist/racism are complex and make use of norms and borders between us and them, and men and women (Lilja \& Martinsson, 2018). 


\section{The Crossroads between Power and Resistance}

As stated above, as "anti-genderism" grows stronger it becomes relevant to discuss current feminist politics, its forms and expressions, as well as the ways in which it interacts with and contests anti-genderist discourses. Feminist-inspired resistance involves the gathering of bodies, but there are also more subtle forms of resistance where the aim is a transformation of norms. Overall, resistance and power entangle, and different forms of power give rise to specific expressions of resistance (Lilja \& Vinthagen, 2014). Power can, for example, be depicted by Robert Dahl's notion of decision-making power, which focuses on those who have "more" power by studying concrete and observable behaviours (Dahl in Lukes, 1974, pp. 12-13). This kind of power generates particular resistance strategies, including demonstrations, concrete vetoes, or boycotts.

Other forms of resistance, however, revolve around norms and the advancement of subversive truths. Resistance, here, often builds on the possibility of a repetition that undermines the force of normalization (Butler, 1997, p. 93). The categories and vocabularies of the dominating force or superior norm are contested through reiteration, re-articulation, or repetition of dominant discourses with a slightly different meaning (Butler, 1995, p. 236). Subversive repetitions can be described as resistance that is played out in or forming a network of mobile points of resistance. Or, in the words of Foucault:

Just as the network of power relations ends by forming a dense web that passes through apparatuses and institutions, without being exactly localized in them, so too the swarm of points of resistance traverses social stratifications and individual unities. (1990b, p. 96)

Other forms of feminist-inspired or provoked resistance can also be distinguished when analyzing Foucault's outline of bio- and/or disciplinary power. Biopower is a technology for managing populations which incorporates certain aspects of disciplinary power (Sharp, Routledge, Philo, \& Paddison, 2000, p. 17). Biopower is about managing the births, deaths, reproduction and illnesses of a population; it functions to "incite, reinforce, control, monitor, optimize and organize" (Foucault, 1976, p. 136). It is a power that is "taking charge of life" (Foucault, 1976, p. 143; Johansson \& Lilja, 2013). State feminism, as will be displayed below, can be understood as management of lives through biopolitical strategies.

In addition, feminist attempts to establish discourses of gender equality are sometimes understood as involving disciplinary elements. Some forms of knowledge are considered the optimum norm. Those who advance other forms of what is considered low-status knowledge sometimes are exposed to examination, detailed surveillance, as well as a complex system of punishments and rewards in order for them to rehabilitate and normalize according to the right knowledge. The idea is that nonconformity with the norm is punishable and to be different is to be inferior (Baaz, Lilja, \& Vinthagen, 2017; Foucault, 1991, pp. 177-184; Lilja \& Vinthagen, 2014). Disciplinary technologies are understood as a tool to advance gender equality discourses as a norm. Thus, power techniques are used in the moment of resistance.

Overall, resistance might be parasitic on, nourish, as well as undermine power. Power is, for example, sometimes created or recreated exactly through the very same resistance that it provokes (Lilja \& Vinthagen, 2014). Among other things, different feminist movements seem to strengthen anti-gender ideas.

\section{Circulating Resistance}

As stated above, some forms of resistance build on the possibility of a repetition that undermines the force of normalization. Through reiteration, re-articulation, and repetition of new notions, dominant discourses are challenged. Subversive repetitions can be described as resistance that circulates and forms a network of mobile points of resistance. This kind of resistance produces new truths and norms.

The \#metoo campaign is an international movement against sexual harassment. Starting in the US, it spread virally across the world during 2017 and is an example of how repeated notions can establish new discourses. The campaign, interestingly, shows how not only power, but also resistance can be transmitted in a "net-like" mode that involves signs, and the recognition of signs, as well as different emotions (intensities). It is resistance that should be analyzed as something circulating among those who share the experiences of bodily suffering and/or fear of sexual abuse and those who, more generally, recognize those experiences as disempowering. Resistance inspires, provokes, generates, encourages, and sometimes discourages, resistance. Circulating resistance works through narratives that inspire new narratives. The narrating appears as an unstable process, whereby discourse can be both an instrument and an effect of resistance. These narratives produce as well as constitute resistance.

One Swedish newspaper described \#metoo as the following: "The campaign is now sweeping through Swedish social media. On Twitter, Facebook and Instagram, women actors, journalists, artists and private individuals witness sexual abuse and harassment at the workplace" (Aftonbladet, 2017, our translation). The \#metoo campaign is an umbrella concept for a repetition of similar stories that (re)appear as people recognize the stories of the campaign, reflect upon them and the feelings that they provoke in relation to their own embodied experiences-i.e., it is resistance that circulates.

Nearly $80 \%$ of the women in Sweden have been subjected to sexual harassment or abuse, according to an opinion poll conducted by Demoskop for the newspaper Expressen (2017). Thereby, recognition plays a cen- 
tral role in the \#metoo movement. Acts of sexual abuse are being recognized, became intelligible, and created an affinity between people (Butler, 2004). Recognition, here, refers to the identification of a narrative from previous encounters or knowledge-an identification that makes it possible for subjects to recognize themselves (or not) in the subject position (Lilja \& Martinsson, 2018).

As Ninni Carlsson (2009) has shown in her research on narratives of having experience of sexual abuse, one precondition for recognition of and the success in mobilizing a political question is a certain discursive preparedness. To be recognized, a group must already have a certain influence and power over the dominant discourses. In this sense, the \#metoo campaign could be understood as being a result of feminist discursive power as well as of female subordination. Interestingly, the \#metoo resistance is productive in the sense that it produces new-but still comprehensible and discursively anchored-narratives and new "truths" about men, masculinity, and gender, thus challenging previous hegemonies and cultures of silence. Here, the Swedish self-image-connected to the Nordic model of gender equality-of being a nation that promotes feminism and equality could be understood as an important precondition enabling the campaign. Without this self-conception, the testimonies during the \#metoo campaign would probably not have had the same political force since not listening to these claims would be compromising. At the same time, the campaign poses a threat to this very self-image, which might explain the ambivalence that the campaign has met in Swedish media.

Circulating resistance is also effective in its production of a larger "we". The emotions involved in \#metoo make people stick with others who are aligned with the movement. This can be illustrated by the narrative of a young Swedish woman stating that: "\#metoo reduces stigma and shame about sexual abuse. As more dare to choose to come up with their stories, a community is founded in shared experiences. Survivors become less lonely and it is often easier to stand for something together with others" (Thulin, 2017). The quotation reveals how emotions of shame contribute to creating a "we" and recognition of joint bodily experiences. Thus, emotions are performative-they do things, they direct bodies and create practices. Emotions are at the very core of loyalties, attachments, humour, and bonds (Ahmed, 2004; see e.g., Scheff, 1990, on social ties, and Goodwin, Jasper, \& Polletta, 2001, on social movements; Foy, Freeland, Miles, Rogers, \& Smith-Lovin, 2014).

As mentioned above, "circulating resistance" demonstrates how not only power but also resistance, can be transmitted in a net-like organization. In this, the \#metoo has effectively succeeded to counter the "cultures of silence". By being so effective in revealing abuses and exposing various wrong-doings, currently many are mobilizing against the movement, branding the victims as "complainers" and defending the male harassers. In Sweden, this became evident, for example, when \#metoo was blamed for the death of Benny Fredriksson, who took his own life in March 2018 after resigning from his position as head of the Kulturhuset Stadsteatern, Stockholm's arts and culture center. Fredriksson was accused of having pushed a woman into having an abortion, and for running the city theatre as a dictator. Reporter Cissi Wallin, however, wrote an article to counter the critique against \#metoo, stating that:

People argue that the \#metoo lies behind Fredriksson's death. I have seriously received emails and comments during the last days where I am blamed ("and other hysterical feminists") for Benny Fredriksson death. It is said that "metoo went too far". But what has actually been going on for too long is the culture of silence. Throughout \#metoo, I've been breaking the culture of silence and relieving the vulnerable of the debt burden they experience. (Wallin, 2018, our translation)

The quotation reveals the anger that the \#metoo campaign has spurred and how "feminists" are pictured as "hysterical" and irrational. Women are pointed to as "bad women", who by revealing sexual abuse have hurt "innocent" men. Thus, the whole \#metoo seems to have caused a strong counter-reaction from emotional men, who now raise their voices as a part of the antigender movement.

Another critique has been that \#metoo is run by powerful and elitist women (Svensson, 2017). Here, feminists are understood as powerful and therefore not legitimate political subjects. This accusation is, as those who have followed the movement in Sweden know, not wellgrounded since the movement contains plenty of initiatives from groups that are far from privileged. The critique is nevertheless interesting since it could be partly understood in relation to Fraser's analysis of the resentment triggered by the emancipation of certain women within a neoliberal context. The political power that certain women manifest seems to be provocative.

Overall, the above text shows resistance as constructive of new norms. However, as will be elaborated on below, feminist resistance not only produces narratives and practices by circulating signs as in \#metoo, but it also takes the form of public assemblies, state feminism, and as "disciplinary resistance" (as well as other forms that will not be discussed here).

\section{Feminist Resistance as Public Assemblies}

Lately, Judith Butler has turned her focus towards the phenomenon of public assemblies. Representations of violence, poverty or other forms of local and global inequalities have made people rise with moral outrage against actions and events that have happened on the other side of the globe. This outrage is not grounded in physical proximity but in solidarity, which emerges across space and time. Images can make suffering at a dis- 
tance seem very close while distancing what is proximate (Butler, 2015, pp. 100, 103). Still, what happens "here" now-as we watch the image-happened "there" before (in previous times when the image was taken). The "timelagged" images impact on our comprehension of reality and ourselves in relation to other "nows" and encourage resistance. Images of suffering create "proxy resistance"; that is, acting out resistance on the part of "subalterns" (Butler, 2015; Lilja, 2017). Active listening, reflexivity, and empathy enable individuals and groups to explore the vulnerability of others, which, in turn, enables proxy resistance (Baaz, Heikkinen, \& Lilja, 2017, 2018).

In Sweden in 2017, as well as in other places, a solidarity act of feminist activists and supporters was to get a "pussy hat" and gather to sing in support of their "sisters" in the US, and elsewhere, against the sexism of Donald Trump. In Washington DC the movement started when over 60,000 women showed up in knitted "pussy power" hats to announce their opposition to Donald Trump's election. The hat was designed as a strategy to, and most importantly, make women visible. The idea was also to, as it started in the US, wear the pussy hat in order to make a unified statement against Donald Trump and protest against his policies towards women, the LGBT community, Muslims, immigrants, and other minorities. Still, both the \#metoo and the "pussy hat" movements have been criticized by black women, women of color, and the black and brown LGBT community, who argue that the campaigns are an attempt of white feminists that fail to include non-white cis and trans-women, thus pinpointing the "pussy hat" as being an artefact that is to be seen as "exclusionary, inappropriate, white-centered, and transphobic" (Gordon, 2018).

Even so, the "pussy hat" movement has spread transnationally and provoked mass-mobilization. Huge gatherings of bodies have been vocalizing their opposition to sexist policies and-due to their embodied, coordinated actions-the demonstrations have signified something in excess of what has been said at different events (Butler, 2015). By virtue of occupying public spaces, the bodies at the demonstrations have been politically "speaking" in a way that is not just vocal or in written language (Butler, 2015, p. 83). Angry, frustrated, touched, or sad bodies gather together to struggle against sexist attitudes, gendered discourses, and marginalization. It is the bodies that convey emotions to other bodies while receiving and forwarding intensities (emotions) themselves. Emotions are forwarded by the subjects of resistance to the readers of these bodies (Lilja, 2017).

In addition, emotions have the tendency to become more intense as they circulate (Ahmed, 2004). When hundreds of women in pink pussy hats met at the International Women's Day in 2017 at Götaplatsen in Gothenburg, the physical settings, the singing, and the multitude of bodies evoked different emotions. Political actions, protests, and demonstrations are spaces where emotions are generated and circulate. Thus, as we decide to visit the setting, we are managing our emotions, which in turn might fuel different resistance acts (Hochschild, 1983).

As revealed above, the \#metoo movement as well as the artefacts of pussy hat are materialities and forms of resistance that have travelled transnationally, affecting people in new venues and thereby being recognized, assumed, made sense of, performed, as well as sometimes rejected in these venues. This kind of resistance is glaring resistance that protests against visible and direct expressions of power. Public assemblies unite humans, and it is a place where resistance becomes scaled up and emotional. Cultural products, such as pink hats, unite people who recognize themselves in each other. Still, this resistance does not seem to evoke any grand counter-movement of backlash. When Googling various internet pages (such as flashback), virtually no comments address or question the "pink hats". Are they not challenging enough? Are they not targeting men in Sweden, but rather subalterns in far-away locations, thus not becoming "dangerous"? One clue could be that the movement, due to its lack of concrete demands, does not endanger the social order of subordination that anti-genderism could be understood to protect. While \#metoo actually resulted in concrete losses, due to social and economic punishments, the pussy hat "movement" did not. To appear does not seem to be enough to destabilize male-privilege and, by implication, it is not the target for anti-genderist discourse. Far more reactions are evoked by the disciplinary resistance described below, which takes place within discourse. Disciplinary resistance aims to establish certain discourses while, according to anti-genderism actors, forbidding those which are understood by feminists to be racist, sexist, or homophobic statements.

\section{Disciplinary Resistance}

Establishing new alternative "truths" that oppose dominant gendered norms seems to be a feminist practice, which is less glaring, rather hidden, and subtle. Stereotyped notions of men and women are often questioned in Sweden and new notions about gender are constantly established and (re)established. For example, a new word "hen" (she/he) has been established lately to dissolve the divide between she and he and open up for other identity positions. The establishing of new "politically correct" words and truths are by some groups, however, interpreted as a disciplinary practice. They experience that a discursive struggle is being played out in which different subjects make different "claims" about the shape of social reality. From the perspective of these groups, their political agendas and ideas are understood by the political elite as less compelling, less politically correct, and less legitimate than different feminist claims (Johansson \& Lilja, 2013).

To analyze this further, it might be worth returning to Foucault and his outline of the discursive production 
of truths. Foucault argues that the production and maintenance of discourse is organized by a number of procedures; the best known being the prohibition of certain ideas. Some statements are excluded from the discourse since they represent the dangerous, false, or forbidden (Foucault, 1993). In short, these processes of ranking and exclusion define what knowledge is true and desirable, and what should be regarded as forbidden or disqualified truths. In today's Sweden, where a discursive struggle is taking place between different groups/individuals who are articulating their claims, some men comprehend their narratives to be judged as less legitimate and less qualified than other more feminist claims. A few men have openly opposed what they comprehend as an oppressive feminist agenda, by advancing other truths. Among these, Pär Ström and Ivan Arpi, who claimamong other things - that social science and gender researchers, famous Swedish journalists, established authors, and cultural personalities have formed a mob in order to suppress them and others who do not believe in feminism. This was addressed by Pär Ström as he, reluctantly, decided to withdraw from the debate on gender and equality:

After five years, I have come to the conclusion that it is impossible to stage a serious debate about gender and equality in Sweden. That's because a debate, by definition, requires at least two opinions, and in regard to gender only one opinion is allowed. If you do not accept feminism, you are not accepted as a debater. (Ström, 2013, our translation)

Pär Ström describes himself and his position as subordinate and argues that today feminist views are normsetting. Ström's and others' statements are kept out of the discourse since their knowledge represents the false or forbidden (Foucault, 1993, pp. 7-9). Thus, from his perspective, feminist discourses are no longer to be regarded solely as subaltern, marginalized discourses but also as disciplinary tools (Eriksson, 2013; Johansson \& Lilja, 2013). The same kind of arguments have been promoted by Ivan Arpi, a political writer and right-wing debater who loudly protests that "gender-studies has become a kind of church at Swedish universities" and that "gender theories are becoming increasingly dominant in Swedish universities and in many other areas" (Arpi, 2017). Arpi also concludes that other views are becoming marginalized, criticized, and hard to promote.

From Ström's, Arpi's, and others' perspectives, feminism has moved from the margins to the center and is currently established and maintained with various disciplinary means. The feminist discourses silence other views, which are then marginalized, removed and placed outside the public discourse. Maria Eriksson summarizes this position by describing the phenomenon of a "wronged white man": "a man who, in spite of belonging to the upper stratum of society, feels powerless and silenced and who takes these feelings as signs that society as a whole has become a feminist project that is oppressive towards men" (Eriksson, 2013).

How widespread Arpi's and Ström's views are in Sweden is difficult to say; however, they seem to be advancing. According to Maria Sveland, a famous Swedish feminist writer, Ström has the ability to mobilize men around different anti-gendered themes. She argues in her blog:

Per Ström has contributed to set the tone in the vulgar debate filled with hatred and threats that he now says he shunned. He was one of the first who was hanging out and naming the women who reported Julian Assange for sex crimes. His blog, which in recent years increasingly served as an epicentre of the anti-feminist movement, has coordinated several drives against various public feminists, including Turteatern's female employees who received both hate emails and death threats when performing SCUM Manifesto. The mob started when Pär Ström wrote a furious blog, which was thereafter followed by hundreds of men who posted aggressive comments. (Sveland, 2013, our translation)

A complicated network of power and resistance emerges in cases where, as it seems, gender inequalities are met by a feminist resistance, which in turn strengthens the very power it protests. Multiple entangled relations of power and resistance reinforce and nurture each other. Or, returning to Arpi and Ström, there is a discursive struggle where a feminist critique and anti-genderism emerge and challenge one another, in an unstable process that has the aim of establishing certain discourses. A similar struggle also takes place within academia, where feminist researchers have demonstrated the different ways in which gender studies comes to be formulated as a threat to gender equality (Fahlgren \& Sjöstedt Landén, 2014).

The discursive struggles between feminist viewpoints and an anti-gendered discourse are to be seen as points of power and resistance, where discourses of power and resistance seem to produce and fuel each other. Making claims about causality in social movement analysis is always difficult. Even if different feminist and antigender discourses seem to interact, is hard to prove that there is an exclusive link between anti-genderism and disciplinary resistance. Thus, how feminist-inspired resistance is intertwined in anti-genderism in a Swedish context needs further exploration.

Ström and Arpi both seem to be provoked by the culture of silence, which feminism, according to them, advances. From their perspective, feminist resistance punishes, ranks, and excludes disqualified truths-thus it involves disciplinary technologies. If that is the case, this would mean that some forms of feminist resistance are contaminated by power or are pursued through, what is usually thought of as, disciplinary techniques of power.

The above could be discussed through Chantal Mouffe's theories of democracy and antagonistic strug- 
gles. According to Mouffe, a prerequisite for the emergence of a vibrant democratic sphere and for it to be sustainable is to turn antagonistic conflicts into agonistic conflicts. This means that within the "we" - which constitutes the political community-the opponent is not considered as an enemy but rather she or he is seen as a legitimate adversary whose right to defend his or her ideas is never questioned. Agonistic confrontations instead of representing a danger to democracy are, in reality, the very condition of its existence (Mouffe, 2005). If we fail to turn antagonistic conflicts into agonistic conflicts, violence, ruptures, and struggles will occur. Thus, according to Mouffe, we must also be open to other competing stories and not discipline people into silence. Today, feminists feel silenced and questioned by the anti-gender movement, while the latter experience feminism as hegemonic, and silencing of other viewpoints. Does this mean that the lack of agonistic conflicts has created an antagonistic conflict, which fuels anti-genderism?

Another alternative would be to embrace the discursive hegemony that has been won by feminists and is acknowledged by Arpi and Ström, in understandingas Wendy Brown does-politics as the exercise of hegemonic power and quest for ideological domination (Brown, 2001, 18ff.). The reactions from anti-genderists such as Arpi and Ström could, from this point of view, be understood as a sign of the need to strengthen the feminist hegemony rather than the opposite.

\section{State Feminism}

Above, we have elaborated different feminist-inspired forms of resistance that often come "from below" and the resistance that this feminist resistance encounters. However, a recently published book by Halley et al. (2018), Governance Feminism: An Introduction, vividly shows how feminist notions also exist within states. In places, such as Sweden, feminism and feminist issues, such as child sexual abuse, sexual harassment, pornography, sexual violence, anti-prostitution and antitrafficking regimes, and prosecutable marital rape, are feminist justice projects that are no longer just grass-root struggles but are moving into the state. Governance feminism is globally distributed and there is also feminist resistance to the power of governing feminism.

In Sweden, the Swedish Social Insurance Agency (Försäkringskassan) is one site where governance feminism is played out. As a matter of policy, the Swedish Social Insurance Agency mainstreams gender issues into all its various practices and documents. Or in other words, it incorporates a gender equality perspective in all policies at all levels and at all stages of its policymaking processes (Swedish Social Insurance Agency, 2013). Through bonuses, policies and gender mainstreaming processes, the Social Insurance Agency organizes human subjects as a population by methods that "reinforce, control, monitor, optimize and organize" (Foucault, 1976, p. 136; Johansson \& Lilja, 2013).
For example, between 1993 and 1996 there was a series of rule changes that could be understood as feminist state policies. Among other things, a father's quota (or "daddy quota") was introduced, which reserves a part of the parental leave period for fathers. These "daddy days" have turned out to be important in organizing people's lives, their subjectivities and world views (Riksförsäkringsverket, 2002). Another example of the "feminist strategies" of the Swedish Social Insurance Agency is the institution's equality bonus, which has encouraged parents to share parental leave. If the parental leave is split between the parents then a monetary bonus will be automatically deposited into their account(s) (Johansson \& Lilja, 2013). The state apparatus has incorporated feminist aims or a feminist resistance, to the extent that gender equality strategies have become attached to governmental techniques. Feminist resistance is becoming entwined with state power to create a complex web of power and resistance.

This pattern has, however, been criticized recently within the Swedish debate, in which Swedish feminism has been accused of being nothing but incorporated into a liberal bureaucratic policy that is designed to give women and men the same opportunities in a given system (Blomberg \& Niskanen, 2013; Johansson \& Lilja, 2013). Among the researchers who have raised critical objections against governance feminism of Sweden, Sara Edenheim and Malin Rönnblom, for example, state that "issues of power and conflicts have been replaced by administrative systems and quality assurance projects" (Edenheim \& Rönnblom, 2012, p. 22). Gender equality strategies in today's Sweden seem, in Edenheim and Rönnblom's opinion, to have become primarily a matter of producing report after report (Johansson \& Lilja, 2013). Maud Eduard, Maria Jansson, and Maria Wendt similarly argue that issues of feminism should be about confrontation, dialogue and knowledge exchange, rather than a consensus between the political parties with regard to gender equality (see also Johansson \& Lilja, 2013; Östergren, 2008, p. 183). Thus, feminist issues that have been moved into the state have informed or fueled other forms of feminism; not least within academic venues where feminist scholars write and protest against the governing feminism (Johansson \& Lilja, 2013).

In addition, LGBT activists have raised their voices arguing that equality struggles around, for example, LGBT issues have not been dealt with by the Swedish state feminist discourse. When the Swedish Gender Equality Acta law that specifies the circumstances in which transsexual and intersexual persons may change their legal sex status - was introduced in 1972, it included a requirement for the patient to be sterile, both in order to be allowed to change legal sex and to undergo sexually corrective abdominal surgery. The law, which was the first of its kind in the world, provided no medical reasons for this requirement. Since the law was introduced in 1972, more than 500 transsexuals have been forced to be sterilized in order to change their sex in Sweden. Researcher 
Signe Bremer has investigated how transsexuals experienced the law. One of her respondents said: "They want to assure, in every way, that freaks as us cannot reproduce ourselves" (Bremer, 2013). It was not until the early 2000 s that the practice began to be questioned, initially by RFSL (Riksförbundet för homosexuellas, bisexuellas, transpersoners och queeras rättigheter [The National association for the rights of homosexuals, bisexuals, trans people and queers]) activists. This can be read as state feminism has not embraced gender equality questions beyond the couplet of men and women. Lena Martinsson, Gabriele Griffins and Katarina Giritli Nygren further argue that Swedish gender equality builds upon and produces nationalist and racialized positions (Martinsson, Griffins, \& Giritli Nygren, 2016, p. 1).

Apart from being criticized by other feminists, state feminism has been the target of many actors within the anti-genderist movement. Arpi, as discussed previously, describes gender studies in terms of a "state religion" (Arpi, 2017). Here, he implies that the Swedish state is ruled by a certain feminist academic agenda. As in the case of \#metoo, feminism is here accused not of being marginalized but of being hegemonic; feminism is accused of having power while claiming to be powerless. By implicitly describing critics of feminism as underdogs in the feminist state of Sweden, Arpi legitimizes his antigenderist critique.

\section{Concluding Discussion: Resistance and Power Intertwined}

This article has explored different forms of feminist resistance by discussing some of its more visible expressions, and how they interact with "anti-genderism". Among other things, the article has shown how resistance sometimes develops into, or overlaps with, different technologies of power. For example, different resistance practices transform, support, or hybridize with disciplinary and state power.

In Foucault's work, some of the main forms of resistance are discursive resistance (including the idea of "reverse discourses"), "counter-conducts", and other anti-authoritarian struggles, which interact with different techniques of the self (Foucault, 1981, 1988, 1990a, 2007, 2009). Similarly, as pinpointed above, feminist resistance can also be described as practices against authorities and the power effects of authoritarian relations (for example, the resistance against the Trump administration) as well as being composed of discursive struggles - as points of resistance that interact with power and which appear as repetitions of signs across time. For instance, as a reaction to the constant separation of the categories of she and he, the word "hen" is currently repeated in Swedish society, which produces a new subject position that can be used. This constructive or productive resistance builds upon the repetition and circulation of signs, which inspire the repetition of new similar signs.
What we can see from the above is a complex network of different forms of resistance that confirm, inspire, and are in conflict with, or create each other. Four different forms of resistance have been discussed above: circulating resistance, disciplinary resistance, state feminism, and feminist resistance as public assemblies. The latter sometimes revolves around cultural artefacts, such as the rainbow flag (pride) or pussy hats. Also, Muslim hijabs have sometimes been artefacts around which feminist-inspired resistance has been mobilized in Sweden. For example, in 2017 people assembled in Gothenburg to fight for the right to wear hijabs and the right to work (Lilja \& Martinsson, 2018).

Different forms of feminist resistance compose different representations of feminist-inspired resistance, which are performative of (sometimes conflicting) understandings of feminism in Swedish society. While being performed, the feminist resistance not only reproduces and re-enacts a set of meanings that are under negotiation, but the resistance practices, as part of different feminist discourses, become targets for antigender campaigns.

As implied above, feminist resistance is sometimes small-scale and circulating, yet grand in its character. The \#metoo campaign is as an example of this kind of resistance, appearing as many small points of resistance, which coalesced to become a widespread form of resistance. The resistance is inspired and made reasonable and legitimate by other resisters, thus resistance is an engine for resistance. The resistance has opened up the possibility of there being a backlash in the form of hate from "angry white men". What is understood as disciplinary resistance by the anti-gender movement also attracts hate and frustration from many anti-gender activists. Public assemblies, on the other hand, are not repeated on an everyday basis and sometimes target the suffering of faraway subjects. As such, it does not seem to raise any visible anti-gender reactions. State feminism is under attack from angry men as well as giving rise to other forms of feminist-inspired struggles, such as LGBT rights or more radical forms of feminist resistance.

Overall, LGBT related resistance often condemns what is considered more traditional and excluding forms of feminist resistance. As a reaction to this, a number of researchers and activists want to bring back feminism to the categories of men and women. For example, Yvonne Hirdman, a well-known feminist researcher, argued in Svenska Dagbladet in 2018:

Why only two sexes-why not three, four, five? So, it has recently been argued for in the gender debate. But with \#metoo we finally got back to the basis of feminism: the relationship between men and women. (Hirdman, 2018, our translation)

The above quotation demonstrates struggles that are not between different forms of resistance, but rather between different feminist viewpoints or due to loyal- 
ties with different precarious groups. Another example of this is how feminist-inspired struggles often address both gender inequalities and different forms of racism. However, some argue that these two aims have undermined the gender part of feminist struggles. Ann Charlott Altstadt argues in Svenska Dagbladet:

Anti-racism has collided with radical feminism and left the latter in ruins....Sexual crimes are increasing significantly, and in some areas in Sweden, women do not dare to go out after dusk. Previously, this had been a feminist issue in Sweden, but people on the left of the political spectrum in Sweden dare not address the problem for fear of being accused of racism. (Altstadt, 2018 , p. 20, our translation)

The above indicates that different feminist-inspired struggles may not only support, but sometimes undermine each other. However, as Butler pinpoints, feminism could make alliances and struggle against different forms of inequalities in a concerted manner. She states:

What is astonishing about the alliances...is that several feminist organizations have worked with queer, gay/lesbian and transgendered people against police violence, but also against militarism, against nationalism, and against the forms of masculinism by which they are supported. (Butler, 2011).

Thus, to embrace and challenge different forms of inequalities must not lead to these struggles undermining each other.

As feminist and resistance researchers, we would say that (feminist) resistance mostly challenges, but also creates and strengthens different power relations, and that this is part of the resistance. This is, we would argue, the reason why different camps within the feminist debate criticize each other. The internal criticism between different forms of feminism is important and could contribute to more effective and inclusive forms of feminist resistance. Different practices of feminist resistance should, constructively, be evaluated, analyzed and (re)constructed. Still, when being too harsh the critique risks questioning and/or weakening other forms of feminist resistance.

This article gives an interpretation of the current state of feminism today (at least in Sweden), which we hope to, with the help of others' input and perspectives, develop in future texts. In order to represent the current state of feminism, choices inevitably had to be made in selecting some forms of feminist resistance. These choices are not grounded in any ultimate truth about what qualifies as the most important feminist resistance at present. The choices mirror our current understandings, which are ultimately based on our own (previous) inquiries and our current knowledge base.

\section{Acknowledgements}

We would like to express our sincere gratitude to the anonymous reviewers for their very helpful comments. This work was supported by the Swedish Research Council under grant 421-2014-1418 and grant 201700881 . We are grateful for the support from the Swedish Research Council.

\section{Conflict of Interests}

The authors declare no conflict of interests.

\section{References}

Aftonbladet. (2017, 7 October). Svenska kvinnor hakar på "Me too" kampanj [Swedish women go for the \#metoo campaign]. Aftonbladet. Retrieved from https://www.aftonbladet.se/nojesbladet/a/b3yEg/ svenska-kvinnor-hakar-pa-me-too-kampanj

Ahmed, S. (2004). Affective economies. Social Text 79, 22(2), 117-139.

Altstadt, A. C. (2018, June 13). Därför vill vänsterkvinnor inte tala om våldtäkterna [Therefore do not leftish women want to talk about rapes]. Svenska Dagbladet. Retrieved from https://www.svd.se/darforvill-vansterkvinnorna-inte-tala-om-valdtakterna

Arpi, I. (2017). Genusvetenkapen är Sveriges egna kreationism [Gender studies is the creationism of Sweden]. Svenska Dagbladet. Retrieved from https:// www.svd.se/genusvetenskapen-ar-sveriges-egen-kre ationism

Baaz, M., Heikkinen, S., \& Lilja, M. (2017). Editorial. Journal of Political Power, 10(2), 27-132.

Baaz, M., Heikkinen, S., \& Lilja, M. (2018). Resistance and emotions: Interrogating crossroads and social change. London and New York, NY: Routledge.

Baaz, M., Lilja, M., \& Vinthagen, S. (2017). Resistance studies as an academic pursuit. Journal of Resistance Studies, 3(1), 10-28.

Blomberg, E., \& Niskanen, K. (2013). Arbete och Jämställdhet: Förändringar under femtio år [Work and gender equality: Changes during the last 50 years]. Stockholm: SNS förlag.

Bremer, S. (2013). Patienten: Vårdar du patienten eller normen? Om sjukvårdens möte med transpersoner [Patients: Do you care for the patient or the norm? About the health systems meeting with transpersons]. In M. Ejd (Ed.), Genusyrsel och normuppror: En antologi om vård, värderingar och jämställda löner [Gender-dizziness and norm revolts: A book about care, values and equal saleries] (pp. 142-161). Stockholm: Vårdförbundet.

Brown, W. (2001). Politics out of history. Princeton, NJ: Princeton University Press.

Butler, J. (1995). Subjection, resistance, resignification. In J. Rajchman (Ed.), The identity in question. New York: Routledge. 
Butler, J. (1997). The psychic life of power: Theories in subjection. Stanford, CA: Stanford University Press.

Butler, J. (2004). Undoing gender. London and New York, NY: Routledge.

Butler, J. (2011). Bodies in alliance and the politics of the street. EIPCP. Retrieved from http://eipcp.net/ transversal/1011/butler/en

Butler, J. (2015). Notes toward a performative theory of assembly. Cambridge, MA: Harvard University Press.

Carlsson, N. (2009). Avslöjandets tid. Kvinnors bearbetning av sexualla övergrepp [Times of revelation. Women's processing of sexual abuse]. Gothenburg: Gothenburg University.

Edenheim, S., \& Rönnblom, M. (2012). Avskaffa jämställdhetspolitiken [Eliminate gender policy]. In $\mathrm{M}$. Eduards, M. Jansson, M. Wendt, \& C. Åse (Eds.), Det heter feminism-20 anspråksfulla förslag för att förändra världen [It's called feminism-20 ambitious proposals to change the world] (pp. 22-27). Stockholm: Hallongrottan.

Eriksson, M. (2013). Wronged white men: What kind of conversation can or should there be between feminism and anti-feminism? Nora-Nordic Journal of Feminist and Gender Research, 21(4), 249-263.

Expressen. (2017, October 17). Emelie: Vi tänker inte vara tysta längre [Emelie: We will not be quiet anymore]. Expressen. Retrieved from https://www. expressen.se/nyheter/jag-ar-ett-levande-bevis-pa-att -sexuellt-ofredande-sker-overallt

Fahlgren, S., \& Sjöstedt Landén, A. (2014). När Genusforskningen Blir ett hot mot jämställdheten: En diskursanalys av en debattartikel [When gender studies becomes a threat to equality: A discourse analysis of a debate article]. Tidskrift för genusvetenskap, 35(1), 7-26.

Faludi, S. (1991). Backlash: The undeclared war against American women. New York, NY: Crown Publishers, Inc.

Foucault, M. (1976). The history of sexuality: The will to knowledge. London: Penguin Books.

Foucault, M. (1981). The history of sexuality, Vol. 1: An introduction. Harmondsworth: Penguin.

Foucault, M. (1988). Technologies of the self. In L. H. Martin, H. Gutman, \& P. H. Hutton (Eds.), Technologies of the self: A seminar with Michel Foucault. Amherst, MA: The University of Massachusetts Press.

Foucault, M. (1990a). The history of sexuality, Vol. 2: The use of pleasure. New York, NY: Vintage.

Foucault, M. (1990b). The history of sexuality, Vol. 1: An introduction. New York, NY: Vintage.

Foucault, M. (1991). Discipline and punish: The birth of the prison. Harmondsworth: Penguin.

Foucault, M. (1993). Diskursens Ordning: Installationsföreläsning vid Collège de France den 2 December 1970 [The order of discourse: Inaugural lecture at the Collège de France, 2 December 1970] (M. Rosengren, Trans.). Stockholm and Stehag: Brutus Östlings bokförlag Symposion.
Foucault, M. (2007). The politics of truth. Los Angeles, CA: Semiotext(e).

Foucault, M. (2009). Security, territory, population: Lectures at the Collège de France 1977-1978 [Lectures at the Collège de France]. London: Picador Pan Macmillan.

Foy, S., Freeland, R., Miles, A., Rogers, K. B., \& SmithLovin, L. (2014). Emotions and affect as source, outcome and resistance to inequality. In J. McLeod, E. Lawler, \& M. Schwalbe (Eds.), Handbook of the social psychology of inequality (pp. 295-324). Dordrecht: Springer.

Fraser, N., \& Jaeggi, R. (2018). Capitalism-A conversation in critical theory. London and New York, NY: Verso.

Gee, J. P., \& Handford, M. (2012). The Routledge handbook of discourse analysis. London and New York, NY: Routledge.

Goodwin, J., Jasper, J. M., \& Polletta, F. (2001). Passionate politics: Emotions and social movements. Chicago, IL: The University of Chicago Press.

Gordon, T. J. (2018, January 7). Pussy hats: The confederate flag for white feminists. Medium. Retrieved from https://medium.com/@shewritestolive/pussyhats-the-confederate-flag-for-white-feminists-7a213 $52 \mathrm{~b} 2 \mathrm{f} 5 \mathrm{e}$

Halley, J., Kotiswaran, P., Rebouché, R., \& Shamir, H. (2018). Governance feminism: An introduction. London and Minneapolis, MN: University of Minnesota Press.

Hirdman, Y. (2018). Äntligen-Metoo återställer ordning [Finally, the metoo brings back the order]. Svenska Dagbladet. Retrieved from https://www.svd.se/vadska-vi-med-hen-till

Hochschild, A. R. (1983). The managed heart. Commercialization of human feeling. Berkeley, CA: University of California Press.

Johansson, E., \& Lilja, M. (2013). Understanding power and performing resistance: Swedish feminists, civil society voices, biopolitics and "angry" men. NoraNordic Journal of Feminist and Gender Research, 21(4), 264-279. doi:10.1080/08038740.2013.858569

Kuhar, R. (2015). Playing with Science: Sexual Citizenship and the Roman Catholic Church counter-narratives in Slovenia and Croatia. Women's Studies International Forum, 49, 84-92.

Kuhar, R., \& Paternotte, D. (2017). The anti-gender movement in comparative perspective. In R. Kuhar \& D. Paternotte (Eds.), Anti-gender campaigns in Europe mobilizing against equality. London and New York, NY: Rowman \& Littlefield.

Lilja, M. (2017). Dangerous bodies, matter and emotions: Public assemblies and embodied resistance. Journal of Political Power, 10(3), 342-352.

Lilja, M., \& Martinsson, L. (2018). Cultural artefacts as nodes for power, resistance and emerging communities of belonging. Manuscript submitted for publication. 
Lilja, M., \& Vinthagen, S. (2014) Sovereign power, disciplinary power and biopower: Resisting what power with what resistance? Journal of Political Power, 7(1), 107-126.

Lilja, M., \& Vinthagen, S. (2018). Dispersed resistance: Unpacking the spectrum and properties of glaring and everyday resistance. Journal of Political Power, 11(2), 211-229.

Lukes, (1974). Power: A radical view. London: Macmillan.

Martinsson, L., Griffins, G., \& Giritli Nygren, K. (2016). Introduction: Challenging the myth of gender equality in Sweden. In L. Martinsson, G. Griffins, \& K. Giritli Nygren (Eds.), Challenging the myth of gender equality in Sweden (pp. 1-22). Bristol: Policy Press.

Mouffe, C. (2005). The return of the political. London: Verso.

Mouffe, C. (2010, October 10). From antagonistic politics to an agonistic public space: An interview with Chantal Mouffe. 3 Quarks Daily. Retrieved from https://www.3quarksdaily.com/3quarksdaily/2010/ 10/from-antagonistic-politics-to-an-agonistic-publicspace-an-interview-with-chantal-mouffe.html

Mulinari, D. (2016). Gender equality under threat? Exploring the paradoxes of an ethno-nationalist political party. In L. Martinsson, G. Griffins, \& K. Giritli Nygren (Eds.), Challenging the myth of gender equality in Sweden (pp. 137-161). Bristol: Policy Press.

Nilsson, A., \& Nyström, Ö. (2018). Högerpopulismen och jämlikheten-En essä [Rightwing populism and equality-An essay]. Stockholm: The Swedish Trade Union Confederation.

Östergren, P. (2008). Efter ord [Afterword]. In P. Östergren (Ed.), F-ordet: Mot en ny feminism [The F-word: Against a new feminism]. Stockholm: Pocketförlaget.

Peeples, J. (2015). Discourse/rhetorical analysis approaches to environment, media, and communication. In A. Hansen \& R. Cox (Eds.), The Routledge handbook of environment and communication. Retrieved from https://www.routledgehandbooks. com/doi/10.4324/9781315887586.ch3

Peto, A. (2016). How are anti-gender movements changing gender studies as a profession? Religion and Gender, 6(2), 297-299.

Riksförsäkringsverket. (2002). Spelade pappamånaden någon roll? Pappornas uttag av föräldrapenning [What role did the "daddy days" play? The father's parental leave]. Stockholm: Riksförsäkringsverket.

Scheff, T. J. (1990). Microsociology: Discourse, emotion and social structure. Chicago, IL: Chicago University Press.
Scott, J. C. (1990). Domination and the arts of resistance: Hidden transcripts. New Haven, CT: Yale University Press.

Sharp, J. P., Routledge, P., Philo, C., \& Paddison, R. (2000). Entanglements of power: Geographies of domination/resistance. In J. Sharp, P. Routledge, C. Philo \& R. Paddison (Eds.), Entanglements of power: Geographies of domination/resistance (pp. 1-42). London: Routledge.

Ström, P. (2013). Efter hot och nidbilder tar jag nu farväl av genusdebatten [After threats I now leave the gender debate]. Debatt. Retrieved from http://debatt. svt.se/2012/11/08/efter-hot-och-nidbilder-tar-jag-nu -farval-av-genusdebatten

Sveland, M. (2013). Pär Ström problem med proportionerna och verklighetsförankringen [Pär Ström's problems with proportions and reality]. Mariasveland.Se. Retrieved from http://www.mariasveland.se /aktuellt/par-stroms-problem-med-proportionernaoch-verklighetsforankringen

Svensson, G. (2017). \#Metoo-upproren är egocentriska och exkluderande [The \#metoo is egocentric and excluding]. Nordinavia. Retrieved from http://nordinavia.se/2017/12/metoo-uppropen-aregocentriska-och-exkluderande

Sverigedemokraterna. (2017, August 28). Fullt rimligt resonera om gränsen för abort [Fully reasonable reason for abortion limit]. Sverigedemokraterna. Retrieved from https://sd.se/fullt-rimligt-resonera-omgransen-abort

Swedish Social Insurance Agency. (2013). Internationella kvinnodagen. Kvinnan i socialförsäkringen. Ny plan ska öka jämställdheten [International Women's Day. The woman in social insurance: New plan to improve equality]. Forsakringskassan. Retrieved from http:// www.forsakringskassan.se/press/pressmeddelanden /pressmeddelande_2013/internationella_kvinnoda gen_kvinnan_i_socialforsakringen

Thulin, H. (2017, October 17). Hashtaggen \#metoo tar över internet: "Tillsammans är vi starka" [Hashtag \#metoo takes over the internet: "Together we are strong"]. 24 Kalmar. Retrieved from http://24kalmar. se/2017/10/17/hashtaggen-metoo-tar-over-internet -tillsammans-ar-vi-starka

Wallin, C. (2018). Cissi Wallin: "Det är inte metoos fel att Benny Fredriksson är död" [Cissi Wallin: it is not \#metoo's fault that Benny Frediksson is dead]. Metro. Retrieved from https://www.metro.se/artikel/cissiwallin-det-är-inte-metoos-fel-att-benny-fredrikssonär-död 


\section{About the Authors}

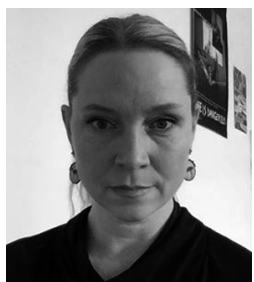

Mona Lilja currently serves as the Professor in Peace and Development Research at the School of Global Studies, University of Gothenburg, Sweden. Her area of interest is the relationship between resistance and social change as well as the particularities - the character and emergence-of various forms of resistance. Some of her papers have appeared in Signs, Global Public Health, Nora, Feminist Review, Alternatives, and Journal of Political Power.

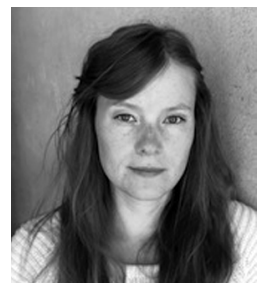

Evelina Johansson is a PhD student in Gender studies at the Department of Cultural Studies at the University of Gothenburg. She writes her PhD thesis on the relation between ethics, politics and neoliberalism within contemporary feminist theory and activism. She has previously published articles in Tidskrift för Genusvetenskap and Nora. 